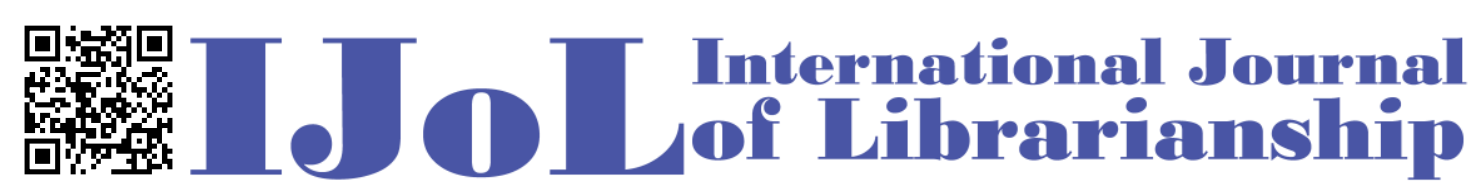

ISSN: 2474-3542 Journal homepage: http://journal.calaijol.org

\title{
ICCPR Article 27 as a Basis for Multilingual Library Services: Implications of Treaty Implementation in the US Context
}

Race MoChridhe

\begin{abstract}
:
In response to a rapidly diversifying population, American libraries have invested considerable effort in improving collections and services in non-English languages. For the past decade, the American Library Association's Guidelines for the Development and Promotion of Multilingual Collections and Services and its Guidelines for Library Services to Spanish-Speaking Library Users have represented the aspirations of the professional community to achieve best practices in this area. At the same time, a growing interest in critically aligning librarianship with human rights work has generated rich reflection on the application of the principles of the Universal Declaration of Human Rights (UDHR). Largely overlooked in this process, however, has been the International Covenant on Civil and Political Rights (ICCPR) which, in contrast to the UDHR, is legally binding on states party and has been ratified by the United States. This article examines the implications of ICCPR Article 27's guarantees of cultural and language rights for minorities on the provision of non-English library collections and services, arguing that the treaty provides a legal foundation for library advocacy to support the work envisioned in the ALA's guideline documents.
\end{abstract}

To cite this article:

MoChridhe, R. (2020). ICCPR article 27 as a basis for multilingual library services: Implications of treaty implementation in the US context. International Journal of Librarianship, 5(1), 61-77. https://doi.org/10.23974/ijol.2020.vol5.1.141

To submit your article to this journal:

Go to https://ojs.calaijol.org/index.php/ijol/about/submissions 


\title{
ICCPR Article 27 as a Basis for Multilingual Library Services: Implications of Treaty Implementation in the US Context
}

\author{
Race MoChridhe \\ American Theological Library Association, Chicago, IL
}

\begin{abstract}
In response to a rapidly diversifying population, American libraries have invested considerable effort in improving collections and services in non-English languages. For the past decade, the American Library Association's Guidelines for the Development and Promotion of Multilingual Collections and Services and its Guidelines for Library Services to Spanish-Speaking Library Users have represented the aspirations of the professional community to achieve best practices in this area. At the same time, a growing interest in critically aligning librarianship with human rights work has generated rich reflection on the application of the principles of the Universal Declaration of Human Rights (UDHR). Largely overlooked in this process, however, has been the International Covenant on Civil and Political Rights (ICCPR) which, in contrast to the UDHR, is legally binding on states party and has been ratified by the United States. This article examines the implications of ICCPR Article 27's guarantees of cultural and language rights for minorities on the provision of non-English library collections and services, arguing that the treaty provides a legal foundation for library advocacy to support the work envisioned in the ALA's guideline documents.
\end{abstract}

Keywords: Multilingual Services, Collection Development, International Covenant on Civil and Political Rights, Universal Declaration of Human Rights, Minority Languages

\section{INTRODUCTION}

The ethnic and linguistic landscape of the United States, always heterogeneous, has rapidly diversified during the first two decades of the twenty-first century. In response, public, school, academic, and special libraries have redoubled efforts to build collections and offer services capable of meeting the information needs of a polyglot population. While individual libraries and library systems have taken a variety of creative approaches to this challenge, the general thrust of efforts over the past decade is well summarized by two documents prepared by the American Library Association (ALA) in 2007, the Guidelines for the Development and Promotion of Multilingual Collections and Services (GDPMCS) and the Guidelines for Library Services to Spanish-Speaking Library Users (GLSSSLU). Recognizing that "little has been done on a national scale to systematically address ... the needs of library-users whose native language is not English" and acknowledging that such populations have been consistently under-served, these documents 
outlined a vision for libraries to "[p]rovide an effective, balanced, and substantial collection for each ethnic, cultural or linguistic group in the community" (GDPMCS).

Although the GDPMCS stresses that "Providing library materials for ethnic, cultural and linguistic groups should not be seen as an 'additional' or 'extra' service, but as an integral part of every library's services," the ALA's guidelines have remained largely aspirational in an atmosphere of budget cuts that limit libraries' abilities both to build and sustain collections and to competitively recruit multilingual staff. It has thus become clear that more than professional good intentions will be needed to render library services effective for the population of twenty-first century America. In an attempt to put these efforts into a larger framework that can enhance library advocacy and make the case for expanded services on multiple fronts, an increasing number of librarians, particularly those aligned with the "critical librarianship" movement, have situated libraries and library services within international human rights discourses, demonstrating how libraries function as vital institutions for realizing the promise of existing human rights instruments.

While this is a promising approach, its efficacy has been limited by near-total focus on the Universal Declaration of Human Rights (UDHR) which, while widely known and powerfully written, is a legally non-binding statement. It is proposed here that, at least within a US context, a more promising tactic may be to connect libraries and library services with the provisions of the International Covenant on Civil and Political Rights (ICCPR) as a legally binding treaty that has been ratified by the United States. Specifically, the potential of the ICCPR's Article 27-which declares that "[i]n those States in which ethnic, religious or linguistic minorities exist, persons belonging to such minorities shall not be denied the right, in community with the other members of their group, to enjoy their own culture, to profess and practice their own religion, or to use their own language" - to provide legal backing to the aspirations for multilingual collections and services embodied in the ALA's guidelines is examined, with indication of both the promises and limitations of such an approach.

\section{LITERATURE REVIEW}

While there are large bodies of work on international human rights law, language as a cultural right, and libraries as mediators and vitalizing agents of cultural heritage, the intersection of these three domains is arguably understudied. As already noted, the majority of literature in this area has aimed primarily at connecting the principles and values of librarianship with the UDHR (e.g. Birdsall 2005; Edwards and Edwards 2010; Sturges and Gastinger 2010; Bowdoin 2011; Mathiesen 2012). One notable exception is the work of Donders (2015), which examines rights of access to information through the provisions of the International Covenant on Economic, Social, and Cultural Rights. The ICCPR appears most frequently in applied analyses of legal frameworks affecting library services and access, particularly for indigenous populations (Morse 2012; Frayne 2018). The present author is aware of no treatment, however, focusing specifically on language rights or applying legal analysis of the ICCPR's cultural rights guarantees to the US context beyond basic consideration of the treaty's status under US law. The present study may therefore be seen as complementary to, and an extension of, those legal analyses that have examined library services with respect to broader cultural rights within other national legal contexts. 


\section{The ICCPR in the United States}

On 8 June 1992, the United States became the 107th state party to ratify the ICCPR, but did so subject to an unusual number of reservations, understandings, and declarations. Most of these have no direct bearing on Article 27, with the exception being the Senate's declaration that "the provisions of Article 1 through 27 of the Covenant are not self-executing" (138 Cong. Rec. S478184, 1992) - a proviso intended to "clarify that the Covenant will not create a private cause of action in U.S. Courts" (S. Exec. Rep. No. 102-23, 1992). On the basis of this declaration, it has been the policy of the United States not to allow plaintiffs to sue for redress under the provisions of the ICCPR within state or federal court. A lack of compliance thus constitutes no immediate domestic legal liability for a US library and there has been no opportunity for domestic courts to build precedent in interpreting the treaty's application in a US context.

This arrangement, however, is of questionable legality. While John Yoo (1999) has defended the use of non-self-execution declarations, Carlos Manuel Vázquez (1992) and Louis Henkin (1995), among others, have argued that the non-self-execution declaration is unconstitutional under the Supremacy Clause, and an argument can also be advanced following the language of the Vienna Convention on the Law of Treaties (not ratified by the United States but acknowledged by the US government as binding insofar as select provisions reflect "customary international law") that it is "incompatible with the object and purpose" of the ICCPR in such a way as to render the declaration void.

It must also be remembered that the intention of non-self-execution declarations is, in contrast to treaty reservations, not to nullify provisions but to delay their domestic application until Congress can pass implementing legislation, which it has accepted responsibility to do through ratification of the treaty. Indeed, it is on account of the failure of Congress to pass such legislation in the more than 35 years since ratification that Jordan Paust (2003) accused the United States of committing a fraud on the international community and that the United Nations Human Rights Committee (HRC) has repeatedly cited the US as neglecting its treaty obligations (HRC, "General Comment No. 24", 1994; "Concluding Observations of the HRC", 2006). Thus, whether one follows the opinion of the majority of legal scholars in holding that the ICCPR is necessarily self-executing and constitutes a legal mandate of immediate import, or simply looks ahead toward the passage of implementing legislation, prudence suggests a close consideration of the treaty itself and of existing precedents in the international courts in order to determine the lineaments of the form that US implementation must eventually assume.

It also deserves to be noted that the HRC agrees to hear cases under the terms of the treaty when these have exhausted "all domestic remedies". In the case Rakhim Mavlonov and Shansiy Sa'di v. Uzbekistan, the HRC determined against a defense mounted by the state party, which claimed that "the decisions of the domestic courts are substantiated and according to the law", noting that the claims of the plaintiffs centered "not [on] the compliance of the actions taken against them by the State party's authorities in accordance with domestic law but rather the noncompliance of the latter with the law of the Covenant". The Committee accordingly concluded that "[ $\mathrm{t}]$ he State party has confused the notions of its domestic law with the autonomous notion of 'law' in article 19, paragraph 3, of the Covenant" and that the appropriateness of domestic court judgements under domestic law was irrelevant to the question of non-compliance with the provisions of the ICCPR. The Committee also observed that "it is a "well established principle of international law and of the Committee's jurisprudence' that one is not required to 'resort to 
appeals that objectively have no prospect of success" and that "it does not matter whether the unavailability of a remedy is de jure or de facto; in either case, a victim is excused from the futile exercise of pursuing it." It would therefore appear that the Senate's declaration of non-selfexecution and the resulting inability to pursue a claim based on the ICCPR in domestic courts is likely to be interpreted by the HRC as indicating a complete absence of "domestic remedies", such that a claim by a US citizen under the terms of the Covenant could theoretically be heard directly by the HRC.

Given the relevant case history, the primary challenges to such a claim would likely be definitional, rather than procedural. At its ratification, France issued a declaration that, because the French constitution makes no legal distinctions between persons according to the categories of culture, religion, or language, France has no "minorities" for the purposes of Article 27. In effect, it is argued that the egalitarian principles of French law necessarily preclude the kinds of legal disadvantage that the article is intended to prevent (Cholewinski, p. 700). It is conceivable that the United States could attempt to have a suit under the ICCPR dismissed on these same grounds. While the French reservation has never been directly challenged in court, however, it has been rebuked by the HRC, which affirmed in General Comment No. 23 that the definition of minority is based not on legal status but on group cohesion through markers of shared cultural, linguistic, or religious identity, and which also observed that:

[s]ome States parties [sic] who claim that they do not discriminate on grounds of ethnicity, language or religion, wrongly contend, on that basis alone, that they have no minorities ... The existence of an ethnic, religious or linguistic minority in a given State party does not depend upon a decision by that State party but requires to be established by objective criteria $(\S 4,5.2)$.

It is therefore unlikely that such a claim would be accepted from the United States.

Other governments have attempted to restrict the applicability of Article 27 to longestablished minorities, either through excluding non-citizens or excluding recent immigrant populations, defined according to varying standards for length of residence (Burchill, 2004). These positions also have been explicitly rejected by the HRC, which has asserted both that "[a] State party may not ... restrict the rights under article 27 to its citizens alone" (\$5.1) and that "[j] ust as they need not be nationals or citizens, they need not be permanent residents. Thus, migrant workers or even visitors in a State party constituting such minorities are entitled not to be denied the exercise of those rights" (\$5.2). This is also the position taken by scholars such as Packer (1999): "the underlying logic of all human rights - to respect the dignity of all human beings - strongly implies that also non-citizens who are substantially inside the polity should enjoy minority rights" (pp. 266-7). In a US context, it would thus seem clear that the guarantees of Article 27 would have to be extended to immigrant and refugee populations of recent origin in addition to those longsettled, as well as to undocumented aliens residing in the country. The US would be unlikely to have a case dismissed on the grounds that the plaintiff was not protected under Article 27 by virtue of membership in any of those groups.

A different definitional problem has arisen insofar as many indigenous populations, such as the Sami and the Mi'kmaq, have resisted classification as minorities under Article 27, fearing that this would undermine their claims to the status of "peoples" within the language of Article 1 (Yupsanis, 2013, p. 374). The trend in rulings, however, has been to acknowledge substantial overlap between these categories (pp. 374-5), with the courts accepting invocations of protection under Article 27 by indigenous communities without regarding this as limiting them to the status 
of "minorities", which might otherwise reduce protections for land rights and otherwise impair the specifics of indigenous claims (pp. 376-7). The precedent is thus that, although considered in a category distinct from that of minorities as envisioned by Article 27, indigenous populations are entitled to claim the protections of Article 27 in addition to their rights enshrined elsewhere. Article 27 would thus seem unproblematically to apply to the scheduled tribes in the United States alongside other minority populations.

Ascertaining that the ICCPR has legal force in the United States and that US residents, both citizens and non-citizens, would have de jure standing to pursue a claim under it before the Human Rights Commission is only an intellectual exercise, however, unless there is a de facto need for US residents to obtain redress under its provisions. Unfortunately, a survey of American library history indicates precisely such a need.

During the First World War, large numbers of libraries removed German-language materials from their collections. The largest loss was at the Cincinnati Public Library, where ten thousand such volumes were taken out of circulation while the Board of Trustees issued a statement in the local newspaper declaring that "English is the language which must become universal in the United States, and the library should be one of the instruments through which this is to be accomplished" (1918, p. 16). When the Supreme Court finally acted against anti-German language discrimination, however, it was through a case (Meyer v. Nebraska) focused on violation of a state law against teaching German. The precedent created thus failed to address the issue of language discrimination in library collections; indeed, the court pointedly avoided First Amendment issues altogether and grounded its decision in the Fourteenth Amendment (Wiley, 1998). Many of the removed materials never returned.

Following a constitutional declaration of English as the official language of California in 1986, the mayor and city council of Monterey Park attempted to block the library from accepting a donation of ten thousand Chinese-language books. The library board held that the gift was consonant with its collection development policy and aided it in meeting the needs of a population that was nearly $50 \%$ Chinese by ethnic origin but which had hitherto been served by a Chineselanguage collection amounting to less than $10 \%$ of the library's holdings. In response, the city council dissolved the library board and assumed direct control, citing the need for "financial accountability." The mayor, meanwhile, was repeatedly quoted in the Los Angeles Times speaking about the danger of the town being overwhelmed by Chinese and insisting that "if people want a foreign language they can go purchase books on their own" (Betancourt, 1992, p. 38). While the city council's actions were successfully challenged by a lawsuit in the Superior Court, neither the original case nor its appeals engaged free speech or minority language rights issues, focusing instead on procedural matters related to the mode of the library board's dismissal (Ward, 1988).

Other "official English" policies have caused less dramatic, but arguably more insidious, disruptions. When Arizona's official English policy led to the mandatory implementation of Structured English Immersion (SEI) programs for the state's English-language learners in the early 2000s, "[f]ear of being accused of offering SEI children too much Spanish affected library policy as well. SEI children were allowed to check out a book in Spanish only if they simultaneously selected one in English. One SEI teacher even denied her students the option of checking out a book in Spanish" (Combs et. al., 2005, p. 16). Similarly, there were reports of school libraries throwing away their Spanish-language holdings as part of their implementation of the new Englishonly curriculum (Hinton, 2015, p. 277). Where books were retained, administrators reported that they were insufficient to meet student demand and Spanish collections consistently included only 
the most basic materials, in contrast to the wide range of reading levels represented by English holdings (p. 278) - this in a state where one out of every five residents speaks Spanish at home.

While these are extreme cases, the inability and/or unwillingness of existing domestic legal frameworks to respond to them in their extremity as issues of language rights throws into relief the marked change that implementation of Article 27 would imply_namely, that the sweeping powers hitherto invoked by state and local governments with respect to the management of library collections and language policies would almost certainly be curtailed. Such curtailment would have roots in existing US law, albeit shallow ones. When the city of Pomona, California enacted an ordinance in 1989 requiring business signs in "non-English characters" to devote equal sign space to "English-language" advertising, the ordinance was struck down by a federal judge on the First Amendment grounds that it regulated language, which the court held to be "an expression of national origin, culture and ethnicity..." The ruling decided that "a person's primary language is an important part of and flows from his/her national origin... choice of language is a form of expression as real as the textual message conveyed. It is an expression of culture" (Asian American Business Group v. City of Pomona). As a trial court decision, however, the precedential value of Pomona has been limited (Del Valle, 2003, p. 63). Other lower court and state supreme court rulings have similarly held that "minority language usage was a fundamental right that could not be abridged except for compelling governmental reasons" (p. 69). Unfortunately, many of these decisions, such as the US District Court for Arizona's ruling in Yniguez v. Mofford, have been overturned or dismissed on procedural grounds (see Arizonans for Official English v. Arizona). While the reasoning behind them has not been faulted, their precedential value is thus further impaired, creating a significant "grey area" around language issues in American law. Sandra del Valle (2003) summarized this status quo as follows:

Complicating the task of integrating language rights into the civil rights world is the fact that language rights law, as a distinct field, is still in development. Indeed, some might say that it does not yet exist as a separate legal area. There are only a few Supreme Court decisions relating specifically to claims made by language minorities, and those ... have been decidedly vague about how to analyze language-based claims, so there is little guidance for the lower courts. Basic decisions, like whether language minorities can be treated for constitutional purposes like ethnic minorities, are still undecided... (p. 4)

At a bare minimum, full implementation of Article 27 would put legal force behind the trend of US court decisions, from Meyer to Pomona to Yniguez, that have gestured toward recognition for minority language rights but which have not, for various reasons, been able to establish an effective precedent within domestic law. Article 27 should thus not be seen as an outside imposition, but rather as a welcome support to the long arc of American jurisprudence that has bent toward linguistic justice.

\section{Implications of Article 27 for Library Collections and Services}

Having ascertained the applicability and compatibility of, as well as the need for, Article 27 in the United States, the question remains: What specific implications does it have for US library collections and services? Perhaps the most fundamental change, with implications in many areas, is that the very distinction between collections and services is blurred when seen through the lens of the HRC's concept of cultural rights. Athanasios Yupsanis (2013) has examined the inclusion of traditional economic activities-Sami reindeer herding, Maori fishing, Aymara llama and 
alpaca raising - as cultural rights in the Committee's precedents, noting how they have been interpreted as crucial to the maintenance of traditional ways of life:

In this way, the Committee distanced itself from the traditional conception of culture as a type of good, an object valuable for its potential to be accessed, consumed, experienced or used, and adopted an alternative view of culture as a way of life consisting inter alia in a set of activities that individuals and peoples must be permitted to pursue (p. 12).

In Cindy Holder's (2008) terms:

what cultural rights protect is the ability of persons and peoples to produce cultures, and to produce them in a way that allows them to describe those cultures as their own. ... [C]ultural rights are essential to human dignity not because they secure individuals in their ability to obtain goods or achieve a specific state of affairs, but because culture is what people do when they are living their lives within a people (p. 22).

With "culture" seen through this lens, a legal imperative is placed behind a shift in perspective already urged within the professional community-namely, that we should see libraries not only as repositories of objects but also as loci of social connections, whether face-toface or mediated through the materials held. Under Article 27, culture is not a commodity loaded in books the way water is stored in jugs or electricity in batteries, awaiting dissemination to the people. Instead, it is a dynamic epiphenomenon arising from the connection made, in the best spirit of Ranganathan, between every reader and her book and every book and its reader. This understanding is already reflected in the work of many library science scholars, such as Donghee Sinn (2012), who admonished that "the viewpoint of digital libraries should change from one of information systems with contents to that of facilitation of intellectual communication among users" (p. 1523).

The practical import of this to libraries' engagement with minority communities, however, becomes clear only in light of a corollary principle the Committee has drawn from the Covenant, which is that the conception of culture as a participatory process entails "not only negative duties to refrain from interfering with people when they are pursuing an interest, but also positive duties to provide people with what they need to ensure that pursuit is successful" (Holder, 2008, pp. 1920). The states party are thus obliged not only to permit minority cultures to practice their traditions and speak their languages without interference or discrimination, but to take positive action to ensure the maintenance of conditions in which those traditions and languages can continue to be developed. Holder (2008) has found some of the strongest implication of this in the HRC's general comment on the obligations of states party, which indicates "not only that cultural rights do not depend on other rights for their justification, but that they may themselves ground rights to conditions, objects or goods that are instrumentally necessary for a people's culture" (p. 10). In other words, Article 27 does not merely provide that one must leave a woman in possession of a book in her language, but that one must also guarantee conditions under which she might have time and opportunity in which to read it, thus grounding subsidiary rights to such goods as basic literacy education and legal limits on working hours, and must also ensure that she is able to enjoy the book "in community with the other members of [her] group". As Holder has written, "a right to culture without security of means to realize and instantiate that culture is an empty protection" (p. 19). 
Such assertions raise more questions than answers, of course, but the great majority of cases that have been brought before the HRC have been claims by indigenous plaintiffs concerning land rights related to preservation of culture, with the result that, as Yupsanis (2013) observed, "linguistic rights ... are to a significant degree missing from the Committee's insight" (p. 405). This has been true even of those cases that have concerned language specifically, such as Diergaardt et al. v. Namibia (2000). In that case, the only petitions brought by the plaintiffs under Article 27 were on land rights issues, and the findings of the Committee related to language discrimination fell under the auspices of Article 26 (although one dissent did note the possibility of a claim being brought under Article 27). Such cases can still be helpful, however, in determining some broad lineaments of likely findings by the HRC if faced with prominent American cases. For example, the Committee in Diergaardt et al. v. Namibia found a violation of Article 26 on equal protections in a Namibian government policy restricting the use of Afrikaans in government communications, with even the dissenting opinions objecting only that a distinction between official and unofficial languages was reasonable and permitted under the provision and that, while Afrikaans received unequal treatment from the government compared with English as the sole official language of the country, it did not receive unequal treatment compared to other unofficial languages. This same defense could not be made, though, of Article XXVIII of the Arizona Constitution which, while recognizing only English as an official language, accords preferential status to Native American languages as against Spanish.

The case most directly engaging minority languages as cultural rights and having the most direct implications for libraries, however, is Mavlonov and Sa'di v. Uzbekistan (2009). There, the HRC found a violation of the Article 27 rights of both the publisher and a reader of a minority language newspaper to which the Uzbek government had, without compelling cause in the eyes of the Committee, denied registration (Donders, pp. 25-6). The details of the Committee's published views on the case with respect to Article 27 are precedentially important and worth noting at length:

8.6 As for the authors' claim under article 27, the Committee explained ... that this article 'establishes and recognizes a right which is conferred on individuals belonging to minority groups and which is distinct from, and additional to, all the other rights which ... [individuals] are already entitled to enjoy under the Covenant'. It specifically noted that the 'protection of these rights is directed towards ensuring the survival and continued development of the cultural, religious and social identity of the minorities concerned'. Finally, the Committee has emphasized that article 27 requires State parties to employ '[p]ositive measures of protection [...] against the acts of the State party itself, whether through its legislative, judicial or administrative authorities [...]'

8.7 In this respect, the Committee has noted the authors' uncontested claim that "Oina" published articles containing educational and other materials ... of cultural interest to this [Tajik] readership, as well as reported on the particular difficulties facing the continued provision of education to Tajik youth in their own language... The Committee considers that in the context of Article 27, education in a minority language is a fundamental part of minority culture....[T] he question of whether Article 27 has been violated is whether the challenged restriction has an 'impact [...] [so] substantial that it does effectively deny to the [complainants] the right to enjoy their cultural rights [...]'. In the circumstances of the present case, the Committee is of the opinion that the use of a minority language press as means of airing issues of significance and importance to the Tajik minority community in Uzbekistan, by both editors and readers, is an essential element of the Tajik minority's culture.

Three elements of this decision are particularly pressing in an American context and with respect to library services. The first is the specific application to school library settings in light of 
the Committee's explicit affirmation of "education in a minority language" as "a fundamental part" of a minority culture and thus as a fundamental object of protection with respect to the rights enshrined in Article 27. It is difficult to imagine the Structured English Immersion programs in states such as Arizona, which led to the denial of Spanish-language reading materials to students, withstanding a challenge before the HRC. At a minimum, the precedent of Diergaardt et al. $v$. Namibia would suggest that the restrictions such programs place on the use of Spanish are unwarranted and inequitable. At a maximum, the Committee might well hold with Tove SkutnabbKangas (1999) that "[e]very time there are indigenous or minority children in day-care centres and schools with no bilingual teachers authorized to use the languages of the children as the regular and main teaching and child care media, this is tantamount to prohibiting the use of minority languages 'in daily intercourse or in schools'."

The second major point is the Committee's finding that "a minority language press ... is an essential element of the Tajik minority's culture" in conjunction with its determination that Sa'di, as a plaintiff, had suffered a violation of his rights under Article 27 by being improperly denied the opportunity to participate in his culture through readership of Mavlonov's newspaper. The potential application of this precedent to minority language collections in libraries is farreaching. Hitherto, we have considered only the potential for Article 27 to provide effective legal remedy against prejudicial exclusions of minority-language material from collections, as in the cases previously mentioned involving German-, Chinese-, and Spanish-language materials. Mavlonov and Sa'di v. Uzbekistan, however, strongly suggests that Article 27 limits the legal authority of libraries and other state agencies to reduce access to minority-language collections even in the absence of a prejudicial intent-for example, drawing down holdings of lowcirculation items as a matter of financial expediency. The implications of this in some parts of the United States could be quite startling, given the presence of large legacy collections assembled decades ago to serve immigrant populations whose descendants have largely transitioned to English. The substantial reduction of those collections in Italian, Polish, Yiddish, and many other languages due to falling circulation may constitute a violation of the Article 27 rights of such members of those communities as have retained the languages in question, obliging state and local authorities to appropriate money and make other allowances for the preservation and continued accessibility of such materials. Once again, this provides legal support to what the professional community has already come to recognize as best practice. As Frans Albarillo (2010) has argued:

\footnotetext{
Socially responsible librarianship includes being able to connect users to information sources of different formats and languages... requir[ing] language training and cultural diversification of the library workforce. ... One of the main challenges that local libraries face is adapting to the changing multicultural landscape and immigration patterns of the communities they serve (p. 93). Inferring language rights from Article 27 means that free participation in the cultural life of a community must also include the right to languages spoken in minority communities (p. 94).
}

Albarillo followed the arguments of Elissavet Stamatopoulou-Robbins (2007, p. 107) concerning Article 27 of the UDHR (which is parallel in content to Article 27 of the ICCPR) but noted in his rebuttal of scholars such as Johannes Morsink (2000, p. 269), whose more conservative views of the text do not allow such an inference, that the ICCPR's Article 27 provides a clearer warrant than the UDHR (Albarillo, 2010, p. 94). "As libraries work to promote cultural rights through Article 27," he wrote, "they must think carefully about both the individual and collective aspects of language access in information work. This means incorporating ... new resources in languages that previously were not on the information radar" (p. 96). 
The third major change implied by Article 27 is to the ways in which resources are managed and allocated. While many, if not most, US libraries make significant efforts to engage minority populations and solicit feedback in the development of collections and the planning of programming, such efforts have hitherto been at libraries' discretion, in keeping with state and local governments' views (despite the ALA's admonitions to the contrary) of minority language services as an "extra". The HRC's interpretation of Article 27, however, posits legal requirements for minority populations affected by proposed policy changes to be involved in the decisionmaking process, although the Committee has never fully clarified what form such involvement must take or the extent of the influence minority populations are entitled to wield within it (Yupsanis, 2013, pp. 388-9). It has, however, stated that "participation in the decision-making process must be effective, which requires not mere consultation but the free, prior and informed consent of the members of the community" (Poma Poma v. Peru, para. 7.6). Thus, while the Committee has generally avoided requiring the extension of a veto power to minority communities except in cases of the most severe existential threats to their cultural survival in land rights cases (Yupsanis, 2013, pp. 399-403), it seems clear that the involvement of minority-language communities in library decisions regarding the collections and programming that serve them will have to be significantly expanded to comply with the standards of the ICCPR. This would be consonant with other emerging human rights standards in the library and archives field, such as the arguments advanced by Melissa Castan and Julie Debeljak (2012) that indigenous peoples should be recognized as " "participants" rather than mere "subjects" of their archival records under section 19 of the Victorian Charter of Human Rights and Responsibilities Act 2006, thus "entailing a requirement for their participation in all decisions by archives and other records institutions pertaining to the holding and management of works by indigenous persons or by non-Indigenous persons but containing Indigenous knowledge" (p. 222).

Among the issues which may assume new saliency in a shared decision-making regime is the currency of minority language collections in light of the obligation imposed by Article 27 to provide for the right of persons to "enjoy their own culture ... in community with the other members of their group." As has been noted, the HRC found in Mavlonov and Sa'di v. Uzbekistan that this right had been denied by the state's failure to ensure the continued availability of a minority-language newspaper it had formerly licensed, which was held to play an essential role in fostering discourse through the minority community's shared print culture. At present, many minority-language collections in US libraries consist of a mix of canonical works of the language's own literature and translations of popular English-language titles. The precedent of Mavlonov and $S a$ 'di suggests that translated works may not meet the aims of Article 27 and that dated collections may do so inadequately. It is conceivable that Article 27 compliance will require libraries also to maintain periodical subscriptions and to acquire representative samplings of current literature.

This may be especially the case in languages that have hitherto been primarily oral traditions and whose literatures are therefore new by default. The HRC's view of culture as a dynamic process has been held to prohibit fixing the terms of a "traditional" way of life to an arbitrary historical point (Firestone \& Lilley, 2005, pp. 216-17). As the Committee indicated in Mahuika et. al. v. New Zealand, "[t] he right to enjoy one's culture cannot be determined in abstract but has to be placed in context [...] Article 27 does not only protect traditional means of livelihood of minorities, but allows also for adaptation of those means to the modern way of life and ensuing technology" (para. 9.4). Similarly, a Finnish case held that the employment of snowmobiles and other modern technology in Sami reindeer hunting did not invalidate claims to preservation of the hunts as a traditional practice (Länsman et. al. v. Finland, para. 9.3). Once again, the Committee's 
views have corollaries in current discourse within the library and archival professions, with Castan and Debeljak having argued that indigenous knowledge continues to be "traditional knowledge" within the framework of the UDHR's Article 27 when it becomes embodied in written records, despite such records not forming a part of "traditional" practice in the Australian Aboriginal communities they considered (p. 220). Written materials containing works in traditionally unwritten languages, as well as audiovisual materials capturing content in sign languages, are thus equally envisioned under Article 27 protections and libraries could conceivably be required to develop their holdings in these areas.

The intersection of such requirements with concerns for the "security of means" (Holder, 2008, p. 19) for participation in the minority culture will be an important area for further exploration as precedents develop. It may be that access to materials through interlibrary loan services will be upheld as adequate provision in many cases, especially where local communities are very small. In other cases, however, strong arguments may be advanced that interlibrary loan cannot guarantee Article 27 rights when, for example, a minority language is a minority even in its homeland and is subject to significant language attrition (i.e. Scottish Gaelic) or governmental restrictions on its use (i.e. Uighur). In those cases, the ability of US libraries to depend on foreign partners for access to materials could be deemed insufficient in light of the heightened risk that overseas collections may be destroyed or that institutions providing access to them may cease operations. Conceivably, this could introduce a legal obligation, if not to create local collections on-site, at least to create central repositories of such materials within the United States to ensure the continuous availability of interlibrary loans.

\section{A Right to Libraries}

Amidst the persistent cuts and austerity regimes that have characterized the library sector for more than a decade, it is certainly unrealistic to expect that libraries will be able to meet these new demands with existing resources. Just as important as stocktaking the new obligations Article 27 would seem to impose is considering how Article 27 repositions the library in the public sphere in such a fashion as to enhance opportunities for library advocacy and to make new demands on governments and other societal structures for the library's support.

As Julie Biando Edwards (2010) observed, "[i]n recent years there has been an increased focus ... on aligning libraries, librarians and library services with human rights principles" (p. 12). One prominent case for such alignment was made by William F. Birdsall (2005), who drew on Jean d'Arcy's concept of the "right to communicate" as a means for integrating the diverse rights of speech, press, privacy, assembly, education, and political participation embodied in existing human rights instruments. This more holistic view, he argued, both allowed and demanded a transformation away from the concept of libraries as supports for the "informed citizen" and toward a concept of libraries as a means for fulfilling the state's responsibility to safeguard and promote the rights of the "communicative citizen" of the twenty-first century. "In this new conception," he wrote, "the legal foundation for the institutional role of the library is the right to communicate. The social role of the library is to ensure all citizens have communicative opportunities to exercise their right to communicate" (p. 80). This posture represents a revolutionary shift in a US context, where the only legal foundation for library services is statutory enactment at the pleasure of state and local legislatures or of Congress. A state legislature or county board that passes starvation budgets for its libraries or decides to shutter them may face public outcry but is entirely within its legal prerogatives as presently understood. 
An approach to libraries as part of the framework of international human rights law could shift that understanding. Kay Mathiesen (2012) built on the work of Alex Byrne (2004) regarding libraries as guarantors of rights of political participation under the UDHR, as well as the work of Paul Sturges and Almuth Gastinger (2010) on the role of information literacy in "ensuring the effectiveness of the right to access information as stated in Article 19 of the UDHR" (Mathiesen, p. 9), to argue for the library as what James Griffin (2008) has called a "derived right"-i.e. a right that follows from a fundamental right "with increasing attention to circumstances" (Griffin, p. 49). Griffin offered the example of "[f]reedom of the press [being] derived, in certain social circumstances, from freedom of expression" (p. 50). While the right to a free press would have been meaningless in societies prior to the press' invention, and remains so in contexts where the economic infrastructure and widespread literacy necessary to support a publishing industry are lacking, a majority of modern societies are organized such that a free press is essential for ensuring the rights of free expression, and a human right to freedom of the press thus arises. Mathiesen argued that, just as "[t]his right [to a free press] derives from the fundamental right along with empirical facts about which institutions can effectively fulfill that right ... the human right to a public library can be derived in the same way from the fundamental right to information" (pp. 910). In this way, Mathiesen was able to craft an argument that international law not only places new demands on libraries to satisfy human rights but imbues libraries with new rights for themselves. As she observed, the HRC's General Comment 14 on the UDHR clarifies that " $t$ t]he right to the highest attainable standard of health" creates a responsibility for states to provide "adequate sanitation facilities, hospitals, clinics and other health-related buildings, trained medical and professional personnel receiving domestically competitive salaries, and essential drugs." Mathiesen argued that "[i]f states fail to take steps to provide these resources there is a prima facie case that they are failing to live up to their obligations under their commitments to human rights treaties" (p. 16).

Julie Biando Edwards (2010) presented a similar case, drawing on the work of Kathleen de la Peña McCook, arguing that libraries should be taken as symbolic of the principles of the UDHR and specifically "that libraries are perhaps the only public institution that can proactively embody the rights set forth in Article 27" (pp. 14-15). As she noted, the connection between libraries and the cultural rights guaranteed by the UDHR's Article 27 (which is concerned with the human right "freely to participate in the cultural life of the community" and is thus analogous to the ICCPR's Article 27) had never before been specifically elucidated in the professional and academic literature on the connections between libraries and community life (p. 15) - an omission she found (p. 28) all the more notable in light of the fact that UNESCO's 1952 "Study of the 'Right to Participate in Cultural Life' Basic Document", which aimed to "analyse the philosophical and legal contents and the principal means of practical application of man's right 'freely to participate in the cultural life of the community," (p. 3) numbered libraries among the select "bodies active in ensuring that all participate in cultural life" (p. 13) and, in its final section, placed libraries first among the institutions that "preserve and promote cultural life" (p. 20). "Thus," Edwards concluded:

as early as 1952, the United Nations recognized libraries as institutions absolutely instrumental for the successful application of Article 27... UNESCO, in singling out libraries in this way, was seeking (as I am) a proactive approach for the promotion of the right freely to participate in the cultural life of the community and is concerned with how libraries can play a central role in such promotion (p. 31). 
In light of the consideration already given to the HRC's ruling in Mavlonov and Sa'div. Uzbekistan and its finding of a violation in the exclusion of a reader from access to a newspaper, it is worth noting particularly, as Edwards did, the UNESCO study's finding that "[ $\mathrm{t}$ ]here may be a personal or non-creative contribution [to the community] in 'receptive' participation in cultural and scientific life," which could occur in many ways, including taking "the form of study and reflection" (p. 11). This breadth of forms of participation was important for Edwards' analysis, as she observed that:

\begin{abstract}
The authors also note in a discussion on the 'means of communication which can be used for the development of cultural life' that "'means of communication" is to be taken in a very wide sense, covering religious ceremonies, dramatic performances, concerts, dancing and ballet, books, reviews, newspapers, public lectures, talks, broadcasting and television, film shows, permanent and temporary exhibitions, club meetings, discussion groups, organized visits to monuments or museums, etc"' [UNESCO, p. 12]. Though the authors of the study clearly associate libraries strictly with books, public librarians in the United States will recognize here many, if not most, of the services their institutions offer patrons. In fact, UNESCO's description of the means of communication reads like a veritable laundry list of services provided by public libraries. With the possible exception of religious ceremonies, libraries - and public libraries in particular - are the one institution offering all of the means of communication, and more, listed as necessary for the development of cultural life" (pp. 32-3).
\end{abstract}

Together, the arguments advanced by Mathiesen on existing precedent for the elaboration of derived rights, alongside those made by Edwards for the library as the paramount institution for ensuring the efficacy of cultural rights protections, are robust and compelling, and they can offer a means for libraries to position themselves not merely as desirable public services but as mandatory human rights provisions, which governments will no longer be free to scale according to their whims. The limitation of these arguments has been that their authors, in common with the authors of the vast majority of literature on libraries and human rights, have rooted them in the UDHR. The symbolic value of that document for initiating and anchoring discussions of selfchosen professional commitments to the furtherance of human rights work is clear, but it necessarily fails as a basis for library advocacy on account of the fact that, as a mere declaration of the UN General Assembly, it is legally non-binding. It is unlikely that any government, much less one with a consistent pattern of contempt for UN instruments and agencies, would feel itself obliged to commit real resources on the grounds of claims to rights derived from a self-consciously aspirational document.

The ICCPR, however, is a legally binding treaty, to which the Supremacy Clause of the US Constitution assures status as "the supreme law of the land". While credible arguments can be advanced both for and against its nature as self-executing, even the most recalcitrant position can argue only that its provisions await implementing legislation to take effect in the United States and cannot deny that after 35 years Congress has more than exhausted the usual delays expected in drafting and passing such legislation after a treaty ratification. Either courts are obliged to act now on a necessarily self-executing instrument or Congress is obliged to act without further delay on implementing legislation. Either way, to the extent that the ICCPR's Article 27 grounds a derived right to library services in general, and to library collections and services in minority languages in particular, the United States government is directly accountable for answering its failures to effectively guarantee those rights as a state party to the Covenant and, in the absence of any means of domestic redress, US residents have standing to bring their cases directly to the attention of the HRC. 
To make the provision of Article 27 an effective force for the protection of minority cultures and the promotion of the libraries that serve them in the US will nonetheless take tremendous energy and resourcefulness. Even supposing that Congress can be made to move forward with implementation, the argument must continue to be made for library services as derived rights akin to those involved in health care, the free press, and other basic institutions of free, modern societies. In particular, advocates will have to be prepared to argue the definition of "available resources":

Articles 26 and 27 articulate what have been called 'second generation rights' which ... [a]ccording to international human rights agreements ... are to be 'progressively realized' within the 'maximum of available resources'... If a state is doing the best it can to use the 'maximum of available resources' progressively to fulfill the right, then it has fulfilled its human rights obligation" (Mathiesen, 2012, p. 16).

The barriers to obtaining redress under the ICCPR thus remain extensive and multi-layered, but the mere fact that the ICCPR holds out the promise of a right to legal redress and of standing before an international court makes it a far more promising platform for advocacy than the UDHR and justifies a shift of focus in the professional and academic discourse, which has for too long centred on the language of a non-binding document. Recognition of the binding force of the ICCPR's Article 27 contextualizes requests for funding and resources as a means for the fulfillment of national objectives hitherto neglected, as observed by the Columbia Law School Human Rights Institute in its brief to the HRC in 2012:

In ratifying the ICCPR, the United States indicated that state and local governments share authority to implement the treaty. ... Despite their critical role, state and local governments continue to lack the necessary training and resources to implement international human rights treaty standards. ... Thus, while state and local agencies and officials have the potential to implement the United States human rights commitments, this potential is largely unrealized (p. 6).

With expansion of collections and services to minority language communities reframed as both a human rights issue and as a legal imperative for the United States to meet its treaty obligations, powerful new tools are afforded to library and community advocates for obtaining needed governmental support.

\section{CONCLUSION}

The confluence of rising interest within the United States in both multilingual services and a human rights framework for librarianship has the potential to radically revision and reinvigorate library relationships with linguistic minorities. The resources to make this possible, however, will only come if human rights discourses not only guide professional standards but also ground library advocacy, which requires a focus on binding instruments to which the United States is a party. At this time, that primarily means the ICCPR. Though the battle will be uphill given the political intransigence of the US government in implementing the treaty over the past three decades, legally rigorous appeal to the provisions of Article 27 offers one of the best prospects for bringing awareness to the unmet needs of minority-language communities and for raising the visibility of libraries as crucial institutions for meeting those needs and hence, more broadly, fulfilling the lofty ideals to which the United States is pledged. 


\section{References}

Albarillo, F. (2010). Cultural rights and language rights in libraries. In Edwards, J. B. \& Edwards, S. P. (Eds.), Beyond Article 19: libraries and social and cultural rights (pp. 85112). Duluth: Library Juice Press.

American Library Association. (2007). Guidelines for the development and promotion of multilingual library collections and services. http://www.ala.org/rusa/resources/guidelines/guidemultilingual

Arizonans for Official English v. Arizona. (1996). 520 U.S. 43.

Asian American Business Group v. City of Pomona. (1989). 716 F. Supp. 1328.

Betancourt, I. (1992). "The Babel myth": The English-only movement and its implications for libraries. Wilson Library Bulletin 66(6), 38-41.

Birdsall, W. F. (2005). Libraries and the communicative citizen in the twenty-first century. Libri, $55(2-3), 75-83$.

Board of Trustees of the Cincinnati Public Library. (1918, May 9). 'Kultur' of the Kaiser's Kind. Cincinnati Enquirer.

Bowdoin, N. T. (2011). Open access, African scholarly publishing, and cultural rights: an exploratory usage and accessibility study. Library Philosophy and Practice (e-journal). Paper 619.

Burchill, R. (2004). Minority Rights. In Conte, A., Davidson, S. \& Burchill, R. Defining Civil and Political Rights: The Jurisprudence of the United Nations Human Rights Committee (Aldershot: Ashgate) p. 189).

Byrne, A. (2004). Libraries and democracy - management implications. Library Management 25(1/2), 11-16.

Castan, M. \& Debeljak, J. (2012). Indigenous peoples' human rights and the Victorian Charter: a framework for reorienting recordkeeping and archival practice. Archival Science 12, 21334. https://doi.org/10.1007/s10502-011-9164-z

Cholewinski, R. (2005). Migrants as minorities: integration and inclusion in the enlarged European Union. JCMS: Journal of Common Market Studies, 43(4), 695-716.

Columbia Law School Human Rights Institute. (2012, December 8). U.S. compliance with the International Covenant on Civil and Political Rights: suggested list of issues to country report task force on the United States. https://www.law.columbia.edu/sites/default/files/microsites/human-rightsinstitute/files/Combined\%20ICCPR\%20submisstions.pdf

Combs, M. C., Evans, C., Fletcher, T., Parra, E., \& Jiménez, A. (2005). Bilingualism for the children: Implementing a dual-language program in an English-only state. Educational Policy, 19(5), 701-728.

Del Valle, S. (2003). Language rights and the law in the United States: Finding our voices (Vol. 40). Multilingual Matters.

Donders, Y. (2015). "International Covenant on Economic, Social and Cultural Rights: accessibility and the right to information.” In McGonagle, T. and Donders, Y. (Eds.), The United Nations and freedom of expression and information: critical perspectives (pp. 89120). Cambridge: Cambridge University Press.

Donders, Y. (2010). Do cultural diversity and human rights make a good match?. International Social Science Journal, 61(199), 15-35.

Edwards, J. B. (2010). Symbolic possibilities. In Edwards, J. B. \& Edwards, S. P. (Eds.), Beyond Article 19: libraries and social and cultural rights (pp. 7-40). Duluth: Library Juice Press. 
Firestone, J. \& Lilley, J. (2005). Aboriginal subsistence whaling and the right to practice and revitalize cultural traditions and customs. Journal of International Wildlife Law and Policy 8, pp. 216-217.

Frayne, A. (2018). "A study of Six Nations Public Library: rights and access to information." Master's thesis, University of Western Ontario. https://pdfs.semanticscholar.org/d97b/f661f75c76fe0937002d289e9004a050d7da.pdf

Griffin, J. (2008). On human rights. New York: Oxford University Press.

Henkin, L. (1995). "U.S. ratification of human rights conventions: the ghost of Senator Bricker". American Journal of International Law 89(2), 341-50.

Hinton, K. A. (2015). "We only teach in English": an examination of bilingual-in-name-only classrooms. In Freeman, Y. S. \& Freeman, D. E. (Eds.). Research on preparing inservice teachers to work effectively with emergent bilinguals (pp. 265-289). Emerald Group Publishing Limited.

Holder, C. (2008). Culture as an activity and human right: an important advance for indigenous peoples and international law. Alternatives, 33(1), 7-28. https://doi.org/10.1177/030437540803300102

Iacovino, L. (2010). Rethinking archival, ethical and legal frameworks for records of Indigenous Australian communities: a participant relationship model of rights and responsibilities. Archival Science 10, 353-372.

Mathiesen, K. (2012, June 10). The human right to a public library. Journal of Information Ethics. https://ssrn.com/abstract=2081178

Morse, B. W. (2012). Indigenous human rights and knowledge in archives, museums, and libraries: some international perspectives with respect to with specific reference to New Zealand and Canada. Archival Science 12, 113-40.

Morsink, J. (2000). The Universal Declaration of Human Rights: origins, drafting, and intent. University of Pennsylvania Press.

Packer. (1999). Problems in defining minorities. In Fottrell, D. \& Bowring, B. (Eds.), Minority and group rights in the new millennium. The Hague: Martinus Nijhoff.

Paust, J. (2003). International law as law of the United States. Carolina Academic Press.

Sinn, D. (2012). Impact of digital archival collections on historical research. Journal of the American Society for Information Science and Technology 63(8), 1521-37.

Skutnabb-Kangas, T. (1999). Linguistic human rights — are you naïve, or what? TESOL Journal, $8(3), 6-12$.

Stamatopoulou-Robbins, E. (2007). Cultural rights in international law: Article 27 of the Universal Declaration of Human Rights and beyond. Brill. https://doi.org/10.1163/ej.9789004157521.i-336

Sturges, P. \& Gastinger, A. (2010). Information literacy as a human right. Libri 60(3), 195-202.

UN Human Rights Committee. (2009, March 27). Ángela Poma Poma v. Peru. Comm. 1457/2006, U.N. Doc. CCPR/C/95/D/1457/2006. http://www.worldcourts.com/hrc/eng/decisions/2009.03.27_Poma_Poma_v_Peru.htm

UN Human Rights Committee. (2009, March 19). Rakhim Mavlonov and Shansiy Sa'di v. Uzbekistan. Comm. 1334/2004, U.N. Doc. CCPR/C/95/D/1334/2004.

UN Human Rights Committee. (2006). Concluding Observations of the HRC: United States of America. U.N. Doc. No. CCPR/C/USA/CO/3/Rev.1. 
UN Human Rights Committee. (2000). J.G.A. Diergaardt (late Captain of the Rehoboth Baster Community) et al. v. Namibia. Comm. 760/1997, U.N. Doc. CCPR/C/69/D/760/1997. http://hrlibrary.umn.edu/undocs/session69/view760.htm

UN Human Rights Committee. (1995). Mahuika et al. v. New Zealand. Comm. 547/1993, U.N. Doc. CCPR/C/55/D/547/1993. http://www.worldcourts.com/hrc/eng/decisions/1995.10.13_Mahuika_v_New_Zealand.ht $\mathrm{m}$

UN Human Rights Committee. (1994, November 8). Länsman et. al. v. Finland. Communication 511/1992, U.N. Doc. CCPR/C/52/D/511/1992. http://hrlibrary.umn.edu/undocs/html/vws511.htm

UN Human Rights Committee. (1994, April 8). CCPR general comment no. 23: Article 27 (rights of minorities). CCPR/C/21/Rev.1/Add.5. https://www.refworld.org/docid/453883fc0.html

UN Human Rights Committee. (1994). General Comment No. 24 (52). U.N. Doc. CCPR/C/21/Rev. 1/Add. 6.

Vázquez, Carlos Manuel (1992). Treaty-based rights and remedies of individuals. Columbia Law Review 92, 1082-1163.

Ward, M. (1988, January 14). In Monterey Park: council sued in takeover of library. Los Angeles Times. https://www.latimes.com/archives/la-xpm-1988-01-14-ga-36045story.html

Wiley, T. G. (1998). The imposition of World War I era English-only policies and the fate of German in North America. In Ricento, T. \& Burnaby, B. (Eds.), Language and politics in the United States and Canada (pp. 211-241). Mahwah, NJ: Lawrence Erlbaum.

Yniguez v. Mofford. (1990). 730 F. Supp. 309.

Yoo, J. C. (1999). Globalism and the Constitution: treaties, non-self-execution, and the original understanding. Columbia Law Review 99(8), 1955-2094.

Yupsanis, A. (2013). Article 27 of the ICCPR revisited - the right to culture as a normative source for minority / indigenous participatory claims in the case law of the Human Rights Committee. Hague Yearbook of International Law 26, 345-383.

\footnotetext{
About the Author

Race MoChridhe, MLIS, currently serves as Scholarly Communication Coordinator for American Theological Library Association (ATLA). His research interests lie at the intersections of library science and applied linguistics, including multilingual services and collections, the role of libraries in language policy and planning, and applications of interlinguistics for improving information processing.
} 